\title{
The Construction of the Guidance Model of College English Writing Teaching
}

\author{
Based on the Writing Center* \\ Shunling Wang \\ School of Foreign Languages \\ Jinan University \\ Jinan, China
}

\begin{abstract}
Adhering to the teaching philosophy of "process writing" and "student-centered" concept, the writing center is a new kind of teaching model with vital and significant reference and guidance to improve Chinese learners' writing level. Based on the analysis of foreign writing center model, this paper summarizes some referential suggestions, such as to build writing center guidance platform, to develop flexible network education guidance form, to build "student-centered" education guidance model of writing, etc.
\end{abstract}

Keywords-writing center; English writing teaching; guidance model

\section{INTRODUCTION}

In the current global world, more talents with excellent foreign language ability and international insights are needed to be equipped with the super competitiveness. Among the language abilities, it's English writing skill that can best reflect the language accomplishment of English learners. [1] However, the English writing ability of Chinese learners is far from being satisfying at present. Although more and more attention has been paid to English writing teaching, the effect has still not met the practical demands at all. The reasons concerned are complicated, and the shortage of timely and effective guidance is one of the main factors. At the present stage, the research focus of Chinese writing teaching is to build a writing teaching model suitable for China's national conditions. [2] In the recent decades, the research focus related to writing theory and practice on "process writing" teaching method is the mainstream, reviewing the essence of writing. Writing Center, originating from North American university, has constructed a kind of new form of writing teaching, employing the "process writing" and "student-centered" teaching philosophy, providing personalized guidance for learners to cultivate excellent writers. Based on writing center, the writing guidance model is of great significance to improve the writing level of Chinese learners and serves as crucial

*Fund Source: 2014 Shandong social science planning project "The research on college English writing fossilization in the second language acquisition" (No: 14CWXJ41) and social science planning project in Shandong province in 2013 "The research on online time characteristics of Chinese learners' English writing" (No: 13CWJJ29). reference to English writing teaching.

\section{SOME RESEARCH ON WRITING CENTER}

In 1983, the International Writing Association Center (IWCA) was established to hold regular work and academic meetings every year to promote the development of writing centers around the world. At present, the writing centers have been widely set up in Asia, Africa, Europe and the United States, the Middle East and Latin America and many other areas of universities. The writing center was first established in Canada and the United States in North America. The Canadian writing center was first established in the 1960s at the University of Toronto and the University of York. The original writing center at the University of Toronto was called the writing lab, which provides "one-toone" personalized tutoring for learners. The Center for Academic Writing in York University provides personal academic writing coaching and helps students become successful writers. At the beginning, the writing center was regarded as a marginalized teaching unit, nicknamed the "fixed-it shop" or "writing clinic", for its teaching and academic status were not recognized then. [3] After years of development, the writing center has gradually become teachers' teaching center, students' intelligence development center and academic development base and its academic status has been widely recognized. In recent years, the Canadian Writing Center Association (CWCA), has been devoted to promoting to advance the development of the writing center in Canadian universities. Basically at least a writing center, even more are set up in some universities. E.g. The university of Toronto has set up 15 writing centers. In addition to one-to-one tutoring, the writing center has also developed writing workshops and online tutorials. Nowadays, the writing center runs through the whole learning process of college students, and has become the core ingredient of college cultural study and life, and has made certain contributions to the theoretical and practical development of college writing teaching. Writing center is, in essence, "a center of consciousness" and a writing "revolutionary" composition content, [4] is an efficient supplement to the classroom teaching in the education system with the ultimate goal of cultivating excellent writers. [5] Some unique coaching methods are created, such as private "one-to-one" 
counselling, various writing topic seminars and online tutoring, actively intervening students' writing at various stages, constructing the correct mode of thinking. Also, some writing courses have also been developed by actively utilizing effective resources and combining them with other majors and disciplines, thus enriching the writing teaching forms. It should be noted that the writing center has opened up a new academic research field and played a positive role in promoting the theoretical and practical researches on writing learning with valuable reference and far-reaching prospect.

Besides, the writing centers set up by universities around the world can also provide us with fruitful references. Duke University offers all types of helps in writing such as brainstorming, the draft writing, revision, in general writing, academic writing, practical writing and other writing guidance. The writing center at Purdue University, the world's most influential writing online instruction center, is a good example of the university writing center with the users hitting ten billion times from 125 countries of the world each year. Texas A\&M University writing center is committed to students' academic potential, in-depth study purposefully through extensive teaching plans. The writing center of Taiwan University in China not only offers academic writing courses for the graduate students of Taiwan University, but also holds seminars to promote the teaching of writing. With various professional requirement for writing ability in college and universities, the writing center in the future will be associated with many departments, various disciplines construction development and more multi-functional writing centers will be widely established at every level in order to meet different learners. Under the background of the rise of "Internet plus", the online writing center will be greatly developed.

\section{The CURRENT SituAtion OF ENGLISH Writing TEACHING IN CHINA}

English writing is an important skill in second language acquisition. In the second language learning environment, writing level of many writing learners tends to be stable and appears to be fossilized. [6] Due to the complexity of various reasons, English writing education seemingly falls into the dilemma of low efficiency.

\section{A. Unreasonable English Writing Courses}

At present, in addition to some writing courses for English majors, the writing course for non-English majors in the colleges and universities in our country is not an independent course, but merely a single part of the reading and writing integrated course. The current curriculum could not meet the requirements of learners of different writing levels. In addition, it's common for most College English class hours to shrink due to the curriculum arrangements. Naturally, the practical problems in English teaching, such as class tension and heavy teaching tasks, are the leading factors to fail to give students timely and effective writing instruction. Of course, it's no hard to see some students lose their interest in writing finally.

\section{B. Relatively Backward Writing Teaching Concept and Content}

In traditional English writing teaching, teachers usually play the leading role, paying enough attention to the model training, focusing on the finished writing products, and often neglecting the guidance of the writing process. The classroom teaching is mainly centered on learners' writing assignments, and mostly stays at the level of sentences and grammar. Hence, writing teaching has easily become an extension of grammar and vocabulary teaching, and is often limited to form, which leads to the lack of specific methods of training and guidance for students' knowledge and logic. In the face of all types of English writing exams, learners are often pressed to write. In the first quarter of 2018, for example, IELTS writing part is involved in the social life consumption, work, education, media, social, cultural and other topics, which not only requires the examinees to have wide knowledge, but also have some writing skills. In this context, it is obvious that the problems in students' writing are caused by the negative influence of Chinese thinking pattern, simplified structure patterns, empty content, illegible logic and frequent language errors, etc.

\section{Simplified Writing Approach and Textbook for Writing Learners}

In summary, college students' English writing learning approach mainly include English classroom, self-study and after-school classes generally. Even some students attain their writing study in after-school classes. The single teaching method of English writing in class cannot meet the diverse writing learning requirements of learners. Domestic English writing teaching materials are mainly targeted for English majors, writing teaching materials or books for nonEnglish majors are mainly exam-oriented at all levels. Little focus is on non-English majors writing theory and practice to guide college students.

\section{TO CONSTRUCT THE GUIDANCE MODEl OF COLlEGE ENGLISH WRITING TEACHING BASED ON THE WRITING CENTER}

In order to change and improve the plight of China's foreign language writing teaching, it's a good try to actively build "student-centered" English writing centers with the combination of China's current foreign language education situation.

\section{A. Firmly Establish the Concept of "Student-centered" Writing Teaching}

As an important part of the international writing researches, the writing center has set up a new way of writing education and has achieved a certain academic status in the world. The writing center focuses on the specific needs of writing learners, attaches importance to the participation and guidance of learners in the writing process, and takes cultivating good authors as the goal of writing education. Currently, it's our task to actively renew education idea, to draw lessons and successful experiences from foreign writing center operation models, to attach great importance 
to the writing process and carefully understand the main difficulties and problems in the learners' English writing. It's our job to firmly establish student-centered teaching concept and build the language ability as the core of writing education guidance model.

\section{B. To Construct the Writing Teaching Guidance Model Guided by the Writing Center}

The writing center is playing the important role in the writing teaching, which tends to be the origin of the writing department in the future. [7] Most importantly, their experience and practices in foreign universities are valuable references for domestic writing teaching research. China now has the largest population of both English learners and teachers in the world, but there are few writing centers. Therefore, it will be a beneficial attempt to apply the writing center operating model in the college English writing instruction practice in China to be supplementary form of the single English writing education in our country. For example, Beijing Jiaotong University has established an international academic communication center for the college teachers and students to provide international academic communication environment and English writing training platform, to offer teachers and students online and offline English writing guidance. Rich experience of writing teaching experts are widely welcomed by all the teachers and students, offering on-site visits and guidance with a variety of types of writing. The writing center of the school of English in Xi'an Foreign Studies University is mainly responsible for individual tutoring to deal with students' writing problems. Sun Yat-sen University, Xi'an Jiaotong -Liverpool University, Zhe Jiang University and other universities in China have also established writing centers based on the practices of north American universities. English writing center highly supports the equal communication and relaxing environment, inspire students to develop independent thinking and make innovation of the new model of English writing teaching.

\section{Attach Importance to the Construction of Writing Guidance Platforms in the Era of Big Data}

With the cloud computing, big data, mobile Internet and other modern information technology profoundly changing the way of human thinking and learning, the influence and impact of information technology on education is increasingly obvious, and plays a more and more important role. Writing is an important activity for human beings to exchange knowledge and express ideas. In the traditional writing teaching, students' writing sometimes cannot get timely correction and feedback because of teachers' heavy workload. On the basis of existing online writing system, it's necessary to actively explore the use of modern information technology such as to use excessive data to build cloud platform for writing guidance center, form an online and offline writing center, help learners find the specific writing instruction suitable for themselves whenever and wherever. Hopefully, writing ability can be improved greatly and the current writing education environment is supposed to develop in diversified directions.

\section{To Actively Explore the English Writing Guidance Model Covering the Whole Writing Process}

In the new era, English writing education also is in the face of the contradiction between diversified demands and insufficient development. According to the present personalized needs of people in foreign language writing and accurate counseling expectations, it's vital for us to draw lessons and successful experiences from the writing center operation model, and promote English writing education need according to the writer's writing purpose and content. Therefore, in order to provide comprehensive quality education services and meet the requirement of more English learners, universities can set up writing centers according to the specific conditions and optimize the writing teaching process. At the same time, colleges and universities should develop and construct writing courses of various majors step by step and provide targeted training according to students' interest and motivation. [8]

\section{CONCLUSION}

Under the development opportunity of "One Belt And One Road" in the new era, the teaching goal of English writing should be globalized, so as to meet the needs of cultivating international competitive talents. To build English writing center with Chinese characteristics guidance mode in a new era, it's vital to get rid of the teaching psychology of "examination-oriented education" and implement "student-centered" education idea, to cultivate students' comprehensive language application ability little by little to meet the new era's need for high level talents.

Talents are usually regarded as the strategic resources to realize national rejuvenation and win the initiative of international competition. Based on the writing center at home and abroad, it's our mission to improve the level of English learners and to cultivate international talents of high quality in China.

\section{REFERENCES}

[1] Liu Runqing. On College English Teaching [M]. Foreign Language Teaching and Research Press, 1999.

[2] Zhang Jie, Zhou Yan. Research on writing teaching practice in Chinese education tradition [J]. Foreign Language, 2017, (5).

[3] Procter, M. Talking the Talk and Walking the Walk: establish the Academic Role of Writing Centres[A]. In Writing in Knowledge Societies[C]. Fort Collins, Colorado: The WAC Clearinghouse and Press, 2011.

[4] North, S. M. Revising "The Idea of a Writing Center"[J]. The Writing Center Journal, 1994, 15, (1).

[5] North, S. M. The Idea of a Writing Center[J]. College English, 1984, $46,(5)$.

[6] Wang Shunling. Fossilization in college English writing and its countermeasures [J]. Chinese Foreign Language, 2008, (6).

[7] Graves, R., \& Graves, H. Writing Centres, Writing Culture: Writing Instruction in Anglo-universities Canadian [C]. Winnipeg: Inkshed Publications, 2006.

[8] Wang Shouren. Some thoughts on college English teaching[J]. Foreign Language Teaching Theory and Practice, 2011, (1). 